\title{
Revealing deep structural influences on the Upper Cretaceous Chalk of East Anglia (UK) through inter-regional geophysical log correlations
}

\author{
M. A. Woods ${ }^{\mathrm{a}, *}$, B. C. Chacksfield ${ }^{\mathrm{b}}$ \\ a: British Geological Survey, Keyworth, Nottingham NG12 5GG, UK \\ b: formerly British Geological Survey \\ *: Corresponding author. Tel.: +44 (0) 1159363155. \\ E-mail address: maw@bgs.ac.uk
}

\begin{abstract}
New borehole geophysical log interpretations between Wiltshire and north Norfolk show detailed lateral changes in the spatial relationships of Chalk Group marker beds. They show how marker beds in the Turonian and Coniacian Chalk Group in East Anglia pass laterally into their correlatives further west, and reveal unusual lateral thickness changes affecting stratigraphical intervals in the East Anglian succession. Newly enhanced regional gravity and magnetic data indicate that these thickness changes are probably related to WNW to ESE trending structural lineaments in the Palaeozoic basement rocks of the buried Anglo-Brabant Massif.
\end{abstract}

The later part of the Mid Turonian and early part of the Late Turonian succession across East Anglia is greatly thickened, and shows almost no lateral variability. These relatively soft, smooth-textured chalks equate with thinner, hard, nodular beds formed in both shallow marine and deeper basinal settings elsewhere in southern England. Since it seems unlikely that there was greater sediment accommodation space across East Anglia at this time compared to basinal areas, this thickening may reflect a localised coccoliths productivity pulse, or perhaps a sheltered palaeogeographical position that protected the area from sediment-winnowing marine currents.

A residual gravity low across north Norfolk, previously interpreted as a granite pluton, may instead represent two elongated (?fault-bounded) sedimentary basins.

Keywords: Chalk, Upper Cretaceous, geophysical logs, structure, gravity, magnetic

\section{Introduction}

The Upper Cretaceous Chalk Group of the United Kingdom can be subdivided into three broad depositional provinces defined by differences in lithology and fauna (Mortimore, 1983; Mortimore et al., 2001). Whilst the successions of southern England (Southern Province) and northern England (Northern Province) are relatively well understood, this is not true of the Chalk of East Anglia (Fig. 1), which largely belongs to the Transitional Province (Mortimore et al., 2001). The East Anglian chalk succession (Fig. 2) is laterally contiguous with that of the Chilterns, Berkshire, Marlborough and Wiltshire downs, areas that also belong to the Transitional Province.

Recent remapping of the Thetford district (England \& Wales 1:50 000 geological sheet 174) by the British Geological Survey (BGS) demonstrated the paucity of inland 
exposure of the Chalk that is typical of East Anglia. Historical data for the Chalk of the region are biased towards biostratigraphy and provide limited understanding of vertical and lateral lithofacies patterns. In contrast, there has been little exploitation of borehole geophysical log data and regional gravity and magnetic data.

\section{Previous Research}

In East Anglia, lack of exposure meant that historical work on the Chalk mainly focused on biozonal mapping, an approach best exemplified by Peake and Hancock (1970). Since publication of this work, about $90 \%$ of the chalk pits upon which it was based have been infilled (Peake and Hancock, 2000a, b). Whilst there has been great progress in the development of lithostratigraphy schemes for the Chalk in northern and southern England (Bristow et al., 1997; Gale, 1995, 1996; Jarvis and Woodroof, 1984; Mortimore, 1986; Mortimore and Pomerol, 1987, Mortimore et al., 2001; Robinson, 1986; Whitham, 1991, 1993; Wood and Smith, 1978), with agreement of a broad stratigraphical framework (Rawson et al., 2001), East Anglia remains poorly understood (Fig. 2).

Work on the use of borehole geophysical logs for correlation in the Chalk Group began in the 1950s and 60s, with the identification of marker-bands on the resistivity log of the BGS Leatherhead (Fetcham Mill) Borehole, Surrey [TQ 1518 5650] (Gray 1958, 1965). Murray (1986) subsequently used these marker-bands to correlate Cenomanian and Turonian successions from the London Basin to East Yorkshire, and more recent log interpretations have recognised the new formational and marker bed stratigraphy of the Chalk Group (Mortimore and Wood, 1986; Mortimore and Pomerol, 1987; Woods and Aldiss, 2004; Woods, 2006).

At the beginning of the BGS work in the Thetford district there was comprehensive reinvestigation of relevant borehole and outcrop biostratigraphical data. The area fortuitously has a wide cover of borehole geophysical log data, as well as numerous borehole observations at Mundford related to a site investigation for a large proton accelerator (Ward et al., 1968; Fig. 1).

\section{Borehole geophysical log data}

At first sight, the correlation of key borehole geophysical logs in the Chalk of the Thetford district looks unremarkable (Fig. 3). Understanding its significance is only possible in the wider context of coeval successions, revealed through interpretation of borehole geophysical logs for the broader Transitional Province extending westwards to Berkshire and Wiltshire (Figs 4, 5). Details of the basis for borehole geophysical log correlations in the Chalk are given in Woods and Aldiss (2004) and Woods (2006).

\subsection{Borehole geophysical log correlation across the Transitional Province}

Figures 4 and 5 show the correlation of borehole geophysical logs across the Transitional Province for Cenomanian to Coniacian strata. Beginning in the far west, core from the Everleigh Borehole allows stratigraphical calibration of its resistivity and gamma logs. The Plenus Marls form a low resistivity spike at the base of the Holywell Nodular Chalk Formation, overlain by higher resistivity log values 
reflecting the typically hard chalk of this formation. The softer New Pit Chalk corresponds with lower resistivity log values; at Everleigh this formation is relatively thin due to erosion and/or condensed sedimentation associated with the lowest hardground of the immediately overlying Chalk Rock (Gale, 1996; Woods and Aldiss, 2004). These hardgrounds are marked by sharply defined high resistivity log peaks.

The interpretation of the Everleigh Borehole is easily extrapolated to logs for boreholes at Horsehall Hill and Banterwick Barn (No. 2), the core from the latter providing further control for correlations (Woods and Aldiss, 2004). The New Pit Chalk is more expanded at Banterwick, with the development of the Glynde Marls at the top of the formation, and the base of the Chalk Rock is also relatively younger. From Banterwick to Braughing/Hamels Mill there is progressive eastward expansion of the New Pit Chalk. Control for these correlations is provided by a group of distinctive low resistivity spikes ('C' on Fig. 4) in the New Pit Chalk, and by the sharply defined low resistivity spike formed by Southerham Marl 1 in the basal part of the Lewes Nodular Chalk. Marker ' $C$ ' in part corresponds with the 'marker marls' of Woods and Aldiss (2004) and Woods (2006, fig. 7), the highest of these low resistivity inflections probably representing the Round Down Marl of Robinson (1986) (= Malling Street Marl of Mortimore (1986); Mortimore et al., 2001, p. 314) (Pearce et al., 2003). North-eastwards into East Anglia, marker ' $C$ ' becomes difficult to trace (Figs 3, 5), and the succession below the Pilgrims' Walk Marl contains the Methwold and Denton Lodge marls (Ward et al., 1968, fig. 3; Murray, 1986, fig. 11; Figs 3, 4, 5). The detailed correlation of this interval is poorly understood.

From Slough eastwards the Lewes Nodular Chalk shows the development of another high resistivity peak, interpreted as the Top Rock based on the Thundridge Borehole (Wood, 1986) and the Baldock Bypass succession (Fig. 4). The Top Rock is a hardground that locally condenses the greater part of the Micraster cortestudinarium Zone (Fig. 2; Wood, 1986). The correlation between Baldock Bypass and Great Chishill is relatively straightforward. In these boreholes two strong gamma peaks represent the Top Rock and Chalk Rock, and below these, the probable correlative of Southerham Marl 1 is developed as a sharp high gamma peak. Lower down in the Great Chishill succession, a series of high gamma peaks probably corresponds to the Glynde Marls at Baldock Bypass; the lowest of the Glynde Marls at Baldock equates with a broad high gamma peak and sharp low resistivity spike in the Great Chishill succession. Slightly lower in the Great Chishill Borehole, the probable horizon of the New Pit Marls (seen at outcrop in the Baldock Bypass section) corresponds with a zone of high gamma peaks and low resistivity spikes. Although the spacing of these markers at Great Chishill is slightly expanded compared to Baldock Bypass, the correlation and stratigraphical trend are confirmed by the group of low resistivity spikes labelled 'C' on Figure 4 (see above).

Boreholes between Great Chishill and Great Bradley are critical in providing a link with the East Anglia succession, and the remainder of the interpretation presented on Figure 4 is best understood by working westwards from Great Bradley towards Great Chishill.

The resistivity log of the Great Bradley Borehole is easily matched with published logs showing the Turonian marl seam stratigraphy in East Anglia, as exemplified by the North Pickenham Borehole (Mortimore and Wood,1986, fig. 2.6), and allows 
identification of the Pilgrims’ Walk Marl, Mount Ephraim Marl, Twin Marl and Grimes Graves Marl. The Great Bradley log also shows high resistivity peaks corresponding with the Chalk Rock and Top Rock. These horizons can be extrapolated westwards into the Haverhill and Westoe Farm boreholes. In the Westoe Farm succession, the Chalk Rock is indicated by a strong gamma and less prominent resistivity peak; a lower, more pronounced resistivity peak has a subdued gamma signature, and probably represents a development of the flint-rich Brandon Flint Series, which is typically associated with the Grimes Graves Marl in East Anglia.

Previously published correlations of the East Anglian marl seams provide the link between the different marl seam nomenclatures extrapolated into the Westoe Farm and Great Chishill boreholes. These correlations demonstrate the following equivalences: Pilgrims’ Walk Marl = Glynde Marls; Mount Ephraim Marl = Southerham Marl 1; Twin Marl = Caburn Marl (Mortimore and Wood, 1986). Based on these interpretations, borehole correlations between Great Chishill and Westow Farm show that strata equivalent to the lower part of the Lewes Nodular Chalk become markedly expanded eastwards into East Anglia. On resistivity logs, the signature of these strata merges with that of the underlying New Pit Chalk, suggesting a reduction in primary cementation. Expansion of the lower Lewes Nodular Chalk is accompanied by corresponding thinning of the underlying New Pit Chalk. The partial resistivity logs for the boreholes at Hempstead and Armitage Bridge allow clear correlation of the Chalk Rock and Top Rock, but interpretation of the Southerham Marl 1 is more speculative.

From Great Bradley north-eastwards, the Pilgrims’ Walk, Mount Ephraim and Twin Marls are a distinctive group of low resistivity log inflections (Fig. 4) that were used by Pattison et al. (1993) to correlate boreholes along the Essex-Suffolk border near Sudbury. Stratigraphical control is provided by the cored Stowlangtoft Borehole (Bristow, 1990), the published interpretation for the North Pickenham Borehole (Mortimore and Wood, 1986), and the cored succession in Borehole 2X at Bircham (Moorlock et al., 2008). Recognition of the Chalk Rock is problematic in some boreholes, especially north of Stowlangtoft where the flint-rich Brandon Flint Series forms a high resistivity peak. Here, identification of the Chalk Rock is aided by interpretation of adjacent marker-beds.

Between the Westoe Farm and Stowlangtoft boreholes there is dramatic thinning between the Mount Ephraim Marl and Plenus Marls (Fig. 5), which is not (as previously) compensated for by further expansion of the lower part of the Lewes Nodular Chalk. This condensed pattern persists northwards across East Anglia (including the Thetford district; Fig. 3), with further slight thinning in the East Harling Borehole. There is also some slight thinning of the high resistivity interval above the Plenus Marls (equivalent to the Holywell Nodular Chalk), but based on the apparent persistence of the distinctive log inflection formed by the Pilgrims' Walk Marl, much of the thinning appears to affect strata equivalent to the New Pit Chalk.

In northern East Anglia, the core and geophysical logs for the Bircham 2X Borehole clearly demonstrate significant northward thinning of the interval between the base of the Chalk and the Plenus Marls compared to the Stowlangtoft Borehole; the succession between the Plenus Marls and Grimes Graves Marl is similarly but less dramatically attenuated. 


\subsection{Borehole geophysical log correlation across the Thetford district}

The above interpretations show that dramatic lateral changes in Chalk sedimentation in East Anglia are not clearly reflected by the persistent marker-bed stratigraphy shown by borehole correlations across the Thetford district (Fig. 3). In addition to the greatly thinned equivalent of the New Pit Chalk and expanded equivalent of the lower Lewes Nodular Chalk, boreholes from the Thetford district also show:

(i) Unusual local thinning of the interval between the Chalk Rock and Top Rock at Mundford

(ii) Eastward expansion of the Top Rock, between Mundford and East Harling, into discrete stratigraphical units, the highest locallystrengthening into a significant hardground in the Square Plantation and East Harling boreholes.

\section{Lithological data}

Despite poor exposure, there are some lithological data that support geophysical evidence for significant lateral changes in Turonian and Coniacian Chalk stratigraphy in East Anglia. The Stowlangtoft Borehole contains an erosion surface with chalk pebbles in the unusually thin equivalent of the New Pit Chalk (largely equating with the interval between the Methwold Marl and Pilgrims' Walk Marl; Figs 2, 4, 5), with a further erosion surface a short distance above the Pilgrims' Walk Marl (Wood and Bristow 1990). Strongly indurated chalk a few metres below the Pilgrims' Walk Marl at $142.79 \mathrm{~m}$, possibly also represents a hardground.

In the Ely-Ouse Borehole 2 [TL 7008 6976], the lowest $20 \mathrm{~m}$ of the T. lata Zone, immediately above shell-rich chalk inferred to equate with the Holywell Nodular Chalk Formation, contains common horizons of large $(50-100 \mathrm{~mm})$ green and buffcoated nodules (Wood and Bristow,1990, p. 21). These records suggest the presence of mineralised hardgrounds and erosion surfaces with glauconite and phosphate, and are below the expected horizon of the Chalk Rock and Top Rock at which levels these features might otherwise be expected.

Finally, digital video log evidence from the Brandon Satellite Borehole (Fig. 6) shows that marl seams in the upper part of the succession are sheared along inclined fracture surfaces, some with listric form based on their digital video log geometry. These probably indicate post-depositional disruption of the succession, but lower down (below the Pilgrims' Walk Marl) disrupted bands of flint nodules around $45 \mathrm{~m}$ and 48 $\mathrm{m}$ depth might reflect syndepositional tectonic processes, since adjacent marl and flint markers are unaffected.

\section{Regional gravity and magnetic data}

The BGS has digital regional gravity and aeromagnetic data for most of the United Kingdom, including the current study area. These data have been used to compile the 1:625 000 scale gravity and magnetic maps of the UK (British Geological Survey, 2007a, b). Although regional gravity and magnetic data have been previously discussed and interpreted in the context of deep basement structure (Lee et al., 1990, 
1993; Busby and Smith, 2001; Busby et al., 1993, 2006), they have not hitherto been used to understand patterns of Mesozoic sedimentation in East Anglia.

Figure 7 shows a colour shaded relief residual Bouguer gravity anomaly map with the key borehole locations plotted; Figure 8 shows the same boreholes plotted on a greyscale shaded relief version of the residual Bouguer gravity anomaly map, overlain by a flat colour reduced-to-pole magnetic anomaly map. In both figures the data have been considerably enhanced by reprocessing, and are much refined compared to that previously published. The residual gravity anomaly map was generated by upwardly continuing the regional gravity field to $2 \mathrm{~km}$ and then removing this field from the observed anomaly; this enhances lateral density variations in the crust attributed to geological sources at shallow depths. The reduced-to-pole magnetic anomaly is the measured Total Field anomaly converted to the field that would be observed at the magnetic pole (vertical field). This has the advantage of simplifying the anomaly pattern and adjusting the location of the anomaly peak to lie immediately over the source.

The residual gravity map shows a prominent structural trend beneath the Chalk outcrop of the central part of East Anglia which is predominantly WNW - ESE. This trend reflects basement structures within the eastern England Caledonide fold belt that forms part of the Anglo-Brabant Massif. Towards the north Norfolk coast the structural trend becomes more fragmented and progressively more $\mathrm{E}-\mathrm{W}$ in nature.

Gravity lows across East Anglia have been modelled primarily as low density Devonian sedimentary basins beneath the Cretaceous (Busby and Smith, 2001). Where these rocks are thin or absent, gravity highs associated with higher density basement rocks generally prevail. In The Wash area, a series of gravity lows with magnetic highs around their margins (Figs 7,8 ) are thought to relate to granite intrusions.

In the Thames Valley region of southern England relatively dense basement rocks make up the London Platform that forms part of the Midlands Microcraton; this is characterised by a gravity pattern that has no strong linear trends in contrast to the East Anglia region. Over the Midlands Microcraton a series of residual gravity lows are present that are associated with important sedimentary basins including the concealed Berkshire and Oxfordshire coalfields. The Midlands Microcraton lies within a broad regional magnetic high whose source is modelled as magnetic, Precambrian Avalonian basement (Busby and Smith, 2001).

The eastern limit of the Midlands Microcraton is poorly defined on the gravity map and its location is very approximate. The broad magnetic anomaly appears to continue beyond the presently mapped eastern limit of the Midlands Microcraton where a broad residual gravity low is also present. This low has been modelled as a thickening sequence of Lower Palaeozoic metasedimentary rocks within a higher density basement, locally overlain by low density Devonian deposits (Busby and Smith, 2001).

The southern margin of the Midlands Microcraton is bounded by the Variscan Front. On the gravity map this is clearly shown as an arcuate $\mathrm{E}-\mathrm{W}$ belt of gravity anomalies, representing the northern limit of Variscan thrusting over the foreland. The 
accepted margin of the Variscan Front based on borehole and seismic data is shown on the magnetic map. The new residual gravity map and gravity modelling (Busby and Smith, 2001), however, suggests that in the Thames Estuary region the margin of the Variscan Front probably lies further to the north.

There appear to be several clear spatial relationships between the regional geophysical data and stratigraphical changes in the Turonian and Coniacian Chalk of East Anglia:

(1) Thinning above the Holywell Nodular Chalk between the Westoe Farm Borehole and the Stowlangtoft Borehole (Fig. 5) spans a major WNW - ESE orientated gravity lineament ('L1' of Fig. 7).

(2) The Mundford site investigation area, with its unusually thin Chalk Rock to Top Rock interval, occupies part of a large gravity high, bounded on its south-west margin by the pronounced gravity lineament described in (1) above.

(3) Regional thinning of the New Pit Chalk and thickening of the lower part of the Lewes Nodular Chalk begins close to the inferred eastern margin of the Midlands Microcraton (Figs 4, 8).

(4) The interval between the Chalk Rock and Top Rock thins close to the north-east margin of the Midlands Microcraton (Figs 4, 8). South-west and north-east of this boundary there is expansion of the interval.

(5) Ely-Ouse Borehole 2, with evidence of Early Turonian mineralised hardgrounds and erosion surfaces, is located close to the major WNW - ESE gravity lineament discussed in (1) (above).

The relationship between the regional geophysical data and boreholes with expanded successions between the Chalk Rock and local 'Top Rock' is less clear. Some of these boreholes occupy gravity highs (East Harling, Kenninghall Water Tower), and some gravity lows (Square Plantation) (Fig. 7), but all are coincident with a small positive magnetic anomaly ('MH8' of Lee et al., 1991, fig. 8) extending north-westwards beyond the East Anglia region (Fig. 8). This magnetic feature is interpreted as probably representing a mid crustal block of more magnetic rocks (Busby et al., 1993), and it is possible that the gravity features may directly relate to structures associated with this and have no significance for Mesozoic sedimentation.

Gravity lineament 'L1' on Figure 7 is a major, low angle, north-east dipping thrust fault, named the Glinton Thrust (Chadwick and Evans, 2005). The fault is possibly of Late Ordovician age, and near Peterborough juxtaposes Late Precambrian and ?Cambrian rocks in the hanging wall (forming the gravity high north-east of the lineament) against Ordovician rocks in its footwall (forming the gravity low immediately south-west of the lineament). The post-Palaeozoic history of this structure is not known in any detail, but the possibility of reactivation during Variscan and Alpine compression and Mesozoic extension has been acknowledged (Chadwick and Evans, 2005). South of the thrust lineament, Figure 7 shows a series of subparallel ESE - WNW gravity features, cut by some sharp NNW - SSE features. 
These may be part of a complex structural fabric, possibly an imbricate thrust stack, associated with the development of the Glinton Thrust. More enigmatic is the narrow NNE - SSW gravity high labelled 'A1' on Figure 7. The orientation of this feature is orthogonal to the regional grain, and it may represent a relay fault developed behind the leading edge of the Glinton Thrust. It is not known if this structure was involved in later reactivation, but such structures might cause structural compartmentalisation of thrusts and affect how different parts of them respond to later movement.

Finally, an elongated mass of granite has previously been speculated to occur at depth across north Norfolk (Allsop, 1985; Smith, 1985; Gallois, 1994; Mortimore et al., 2001, fig. 1.15), approximately coincident with the areas of dark blue shading indicative of a residual gravity low around Saxthorpe north of Norwich, and extending west-north-west to incorporate the granites believed to occur at depth near The Wash (see above; Fig. 7). This putative granite has been linked to the development of an Upper Cretaceous basin high that caused condensed sedimentation across north Norfolk (Mortimore et al., 2001), exemplified by the northward thinning trend of Cenomanian to Early Coniacian strata across East Anglia shown on Figure 5 and commented upon by previous workers (e.g. Jukes-Browne and Hill, 1903; Peake and Hancock, 1970). This granite has never been proved, and whilst evidence is strong for the Wash granite intrusions, the new residual gravity map for the area north of Norwich shows two separate gravity lows hereabouts ('A2' of Fig. 7), with a strong linear trend. The Wash granites ('A3' of Fig. 7) are characterised by local circular gravity lows that punctuate the structural grain, and have magnetic anomalies around their margins. In contrast the linear gravity lows across north Norfolk follow the structural grain, lack magnetic anomalies, and are too narrow, linear and sinuous to be fault-bounded granites. This suggests the presence of two locally developed (possibly fault-bounded) sedimentary basins rather than a granite pluton. How this new interpretation fits with the established model of a Upper Cretaceous basin-high across north Norfolk has still to be resolved. However, it is possible that other aspects of the palaeogrography and structure of the northern margin of the London-Brabant Massif were significant in generating regional thinning of the Cenomanian to Coniacian succession in north Norfolk.

\section{Regional interpretation}

Upper Cretaceous tectonic events affected parts of the Chalk succession across southern England (Mortimore and Pomerol, 1997; Mortimore et al., 1998), but have not been documented in East Anglia or from strata pre-dating the Late Turonian. However, the evidence of stratal thinning, erosion surfaces, pebble beds and hardgrounds, all spatially associated with a major basement fault, is strongly indicative of local structural control on sedimentation in this region. Older Turonian and Cenomanian strata in the Stowlangtoft succession show no unusual thickness or stratigraphy that might otherwise be attributed to long-lived features of basin architecture. It therefore seems likely that the Glinton Thrust and allied structures in the Palaeozoic basement were rejuvenated sometime in the Early to Mid Turonian, affecting the development of the contemporary stratigraphy. The equivalent succession in the lower part of the Brandon Satellite Borehole ('17' of Fig. 7), with disrupted flint bands, an erosion surface and chalk pebble bed, appears to be sited on a minor gravity lineament ('L2' of Fig. 7) in the hanging wall of the Glinton Thrust, 
and may be related to synsedimentary rejuvenation of a subsidiary fault cutting the upthrown block of this structure.

The onset of more gradual thinning of the top Holywell Chalk - Pilgrims' Walk Marl interval that coincides with the eastern edge of the Midlands Microcraton (Fig. 7), between the Braughing/Hamels Mills Borehole and the Westoe Farm Borehole, may be related to the different Mesozoic sedimentation histories of the microcraton and the Anglo-Brabant Massif. Basin subsidence rates were generally low across the whole of the UK during the Upper Cretaceous, and dominated by compactional subsidence (Chadwick, 1985). The relatively thick pre-Chalk Mesozoic succession above the southern part of the Midlands Microcraton was probably able to compact more and accommodate more sediment compared to the thin pre-Chalk Mesozoic cover of the submerged Anglo-Brabant Massif.

From the late Mid Turonian to early Late Turonian, the succession between the Pilgrims’ Walk Marl and Grimes Graves Marl exhibits a laterally persistent stratigraphy across much of East Anglia, with no evidence of local structural control. The thick (c. $40 \mathrm{~m}$ ), smooth or weakly nodular chalk between the Pilgrims' Walk Marl and Grimes Graves Marl contrasts with areas further west, where coeval strata are thin (5-15 m), hard, nodular chalk with hardgrounds, forming a more extreme development of the Chalk Rock. This succession is developed across a broad shelfal area (Berkshire - Chilterns Shelf; Mortimore, 1983) at a time of generally lowered sea level, but even the basinal Sussex Trough (Mortimore, 1983, p. 33) succession is thinner (less than $20 \mathrm{~m}$ ), harder and more nodular than in East Anglia (Mortimore, 1986, fig. 12). With widespread evidence of restricted sedimentation at this time, why is East Anglia so different? Given that tectonically induced thinning occurred in the Early to Mid Turonian, it seems unlikely that there was any more accommodation space for later Turonian sediments in East Anglia compared to the Sussex Trough. Possible answers to this are greater coccolith productivity in response to nutrient enrichment (Mutterlose et al., 2005; Schulz et al., 2004), or a sheltered palaeogeographical aspect that protected the region from sediment erosion.

The unusually thin Chalk Rock to Top Rock interval at Mundford may reflect renewed structural influence on chalk sedimentation in East Anglia. The positive gravity anomaly ('A4' of Fig. 7) on the upthrow side of the Glinton Thrust, immediately north of the thrust gravity lineament, has a distinct wedge shaped geometry. The intensity of the positive anomaly increases at the north-western end towards Mundford, suggesting that there may have been greater upward displacement of this part of the hanging wall block relative to the south-eastern end. The Mundford site investigation area, at the north-western end of the anomaly, appears to be located on a subsidiary structure ('L2' of Fig. 7) cutting the upthrow side of the Glinton Thrust. The very thin interval between the Chalk Rock and Top Rock in the Mundford site investigation area is consistent with this area experiencing greater intra-Turonian inversion.

South-east of Mundford, in the upthrown portion of the Glinton Thrust near Bury St Edmunds and the Stowlangtoft Borehole, the Top Rock weakens and is replaced by iron-stained nodular chalk (Bristow, 1990), suggesting that Early Coniacian rejuvenation of the Glinton Thrust complex was laterally variable. Weakening of the Top Rock appears to form part of a general trend of progressive northward 
sedimentary expansion that begins north-east of the Baldock area (Figs 3 - 5); a trend confirmed by comparison of the outcrop successions at Kensworth [TL 017 197], near Luton, and Reed [TL 3595 3704], near Royston (Hopson et al.,1996, fig. 17). The hardground(s) that strengthen to form the 'Top Rock' in the Square Plantation, East Harling and Kenninghall boreholes appear to be higher in the stratigraphical succession (Fig. 9).

Regional thinning of the Chalk Rock to Top Rock interval at the north-eastern margin of the Midlands Microcraton, reaching a minimum thickness in the Baldock area (Figs 4,5 ), suggests that, at times, the eastern edge of the microcraton might have acted as a structural boundary or perhaps hinge point between areas of differing regional compactional subsidence. Bromley and Gale (1982, p. 290) also commented on the remarkably rapid eastward weakening of the Chalk Rock itself, between the Baldock area and Reed [TL 359 371] (Figs 7, 8), and again structures marginal to the Midlands Microcraton seem the most plausible explanation. At Barton-le-Clay near Luton (Figs 7, 8), a fault or monoclinal fold known as the 'Lilly Bottom Structure' affects the thickness of the Grey Chalk Subgroup and delimits the south-western extent of the Cambridge Greensand at the base of the Chalk (Shephard-Thorn et al., 1994). A major thrust fault complex (Thringston Fault and allied structures) occurs just inside the eastern margin of the Midlands Microcraton (Smith et al., 2005; Pharaoh et al., 2011, fig. 5), approximately coincident with the 'Lilly Bottom Structure'. Later periods of reactivation of this thrust complex may be the underlying cause of these stratigraphical changes, as also suggested by Bailey and Wood (2010).

\section{Intra-Cretaceous tectonic events}

Late Cretaceous tectonic events in Germany, known as the Subhercynian tectonic phases, are expressed in the Chalk of the Anglo-Paris Basin (Mortimore et al.,1998). The earliest of these recorded in English successions is the Ilsede Event, and affects latest Turonian to Coniacian strata. In Germany, older Turonian tectonic events predating the Ilsede Event, are represented by slumped and faulted strata in the Söhlde quarries, near Hannover (Ernst et al., 1998). The latter mainly coincide with the interval between deposition of the Glynde and Caburn marls, but there is also evidence for displacements affecting older strata that are probably broadly synchronous with the inferred reactivation of the Glinton Thrust (Ernst et al., 1998; C. J. Wood, pers. comm., 2011).

Dating of the Ilsede Event broadly correlates with the interval associated with the Top Rock (Mortimore et al., 1998), and is a likely cause of the thin succession between the Chalk Rock and Top Rock at Mundford (Fig. 3). It could also have affected the behaviour of the Midlands Microcraton and contributed to thinning between the Chalk Rock and Top Rock at the north-east margin of this structure around Baldock. Across the Anglo-Paris Basin, this tectonic phase is characterised by the development of submarine slides, onlap of hardgrounds and channel development (Mortimore et al., 1998). If reactivation of faults marginal to the Midlands Microcraton is also responsible for the depositional changes associated with the 'Lilly Bottom Structure', then this would be evidence for a pre-Turonian Upper Cretaceous tectonic event. 
Kley and Voigt (2008) showed that intra-Cretaceous basin inversion in central Europe was related to a change in the relative motion between the European and African plates, unrelated to early Alpine orogenic movements. This change established a compressional stress regime with SSW - NNE-directed thrusting and folding and reactivation of basement structures. The new stress regime developed across Europe, affecting the relatively weak, structurally fragmented lithosphere between the African and Baltic cratonic blocks, and is the likely cause of the Subhercynian tectonic events (Kley and Voigt, 2008). The onset of this new palaeostress regime is dated at about $90 \mathrm{Ma}$ (Kley and Voigt, 2008), approximately synchronous with the stratigraphical thinning of early Mid Turonian sediments seen in the Stowlangtoft Borehole. Whilst this is strong circumstantial evidence for a link to rejuvenation of the Glinton Thrust, the structural mechanisms involved are unclear; north-eastward underthrusting by the footwall is one possibility (Fig. 7). Busby and Smith (2001, fig. 6) illustrated the pronounced shallowing of rigid magnetic basement rocks in southern East Anglia compared to southern England. It is possible that this caused local intensification of Early Turonian stresses in the cover succession which, in the absence of southwesterly dipping discontinuities, were sufficient to cause undercutting of the hanging wall of the north-easterly dipping Glinton Thrust.

Basement structures may have influenced later Alpine deformation of the Chalk in East Anglia, with possible implications for understanding of how the Chalk behaves as an aquifer in this region. Evidence of this later deformation phase is provided by the oblique, marl-lined fractures intersecting marl seams in the upper part of the Brandon Satellite Borehole (Fig. 6). Sealed fractures of this type may locally compartmentalise the aquifer, or if unsealed, locally assist water flow through the aquifer. The Brandon Satellite Borehole is at the periphery of the same large positive gravity anomaly occupied by Mundford, on the upthrow side of the Glinton Thrust. Perhaps more significantly, the borehole appears to be on the alignment of a strong gravity lineament developed immediately west of the borehole, obliquely intersecting the Glinton Thrust (Fig. 7). Since the main Alpine compression event, in the Miocene, represents a NNW convergent palaeostress field, any reactivation of structures in East Anglia with the alignment of the Glinton Thrust is likely to have been broadly strike slip mode, but with the potential for transpression or transtension depending on the local structural fabric.

\section{Conclusions}

Inter-regional borehole geophysical log correlations establish a much clearer link between the Chalk marker-bed stratigraphy of the Berkshire - Chilterns area and East Anglia. The correlations reveal unusual relative thickness patterns for units of Mid Turonian to Early Coniacian strata in East Anglia. Regional gravity and magnetic data suggest that part of this variability is caused by two discrete phases of intraCretaceous tectonic reactivation of basement structures. The margin of the Midlands Microcraton and a major WNW - ESE Caledonian thrust lineament in the buried Anglo-Brabant Massif, named the Glinton Thrust, appear to be especially significant. This interpretation is supported by the limited available lithological data from boreholes and outcrops. Structural reactivation is broadly synchronous with the onset of a north-east directed compressive stress regime in the Early to Mid Turonian, which was also responsible for the Subhercynian tectonic phases reported in Germany 
and elsewhere in the Anglo-Paris Basin. Late Turonian to Early Coniacian structural reactivation in East Anglia, locally affecting the Chalk Rock to Top Rock interval, probably equates with the Ilsede tectonic event of German successions.

In contrast, the succession between the Pilgrims' Walk Marl and Chalk Rock is very uniformly developed across East Anglia, and much thicker and less indurated than correlative strata on the Chilterns Shelf or in the Sussex Trough. It contains a consistently developed suite of named marl seams that give the impression of overall lateral continuity in the Chalk of East Anglia. In the absence of any evidence for these features reflecting greater accommodation space for deposition, it is tentatively suggested that this chalk interval might reflect enhanced nannoplankton productivity, or perhaps a basin-setting that was sheltered from erosive marine currents.

Underlying structures probably continued to reactivate during post-Cretaceous Alpine tectonism, affecting local chalk deformation and fracturing, and possibly influencing the extent to which fractures became sealed by clay remobilised from intercalated marl seams. All these effects are potentially highly significant for improved hydrological understanding of the Chalk in East Anglia, where this geological unit is a major aquifer.

\section{Acknowledgements}

We are grateful to Chris Wood (Scops Geological Services Ltd) for information about Early Turonian successions in Germany and for valuable suggestions for improvements to this manuscript. Alex Gallagher (formerly BGS, Wallingford) provided geophysical and video logging of the Brandon Satellite and Kenninghall Water Tower boreholes. We also thank James Jordan (Anglian Water Ltd) for generously allowing access to borehole geophysical log and video log data, and for allowing access for new borehole logging. Dr. H. W. Bailey (Network Stratigraphical Consulting) kindly provided details of the Chalk succession at Baldock and provided useful discussion of North Sea Chalk stratigraphy. Dr T. Pharaoh (BGS) provided valuable discussion about the deep structure of East Anglia. S. G. Molyneux and A. N. Morigi (BGS) provided early manuscript reviews. M. A. Woods, B. C. Chacksfield publish with the permission of the Executive Director of the British Geological Survey (NERC).

\section{References}

Allsop, J. M., 1985. Geophysical investigations into the extent of the Devonian rocks beneath East Anglia. Proceedings of the Geologists Association 96, 371-9.

Bailey, H. W., Wood, C. J. 2010. The Upper Cretaceous Chalk. 36 - 60 in Hertfordshire Geology and Landscape. Catt, J. (editor). (Welwyn Garden City: Hertfordshire Natural History Society.)

Bristow, C. R., 1990. Geology of the country around Bury St Edmunds. Memoir of the British Geological Survey, Sheet 189 (England \& Wales). 
Bristow, C. R., Mortimore, R. N.,Wood, C. J., 1997. Lithostratigraphy for mapping the Chalk of southern England. Proceedings of the Geologists' Association 108, 293 315.

British Geological Survey, 2007a. 1:625 000 scale Gravity Anomaly Map UK South. Chacksfield, B. C. (compiler). British Geological Survey, Keyworth, Nottingham, United Kingdom.

British Geological Survey, 2007b. 1:625 000 scale Magnetic Anomaly Map UK South. Chacksfield, B. C. (compiler). British Geological Survey, Keyworth, Nottingham, United Kingdom.

Bromley, R. G., Gale, A. S., 1982. The lithostratigraphy of the English Chalk Rock. Cretaceous Research 3, 273 - 306.

Busby, J. P., Kimbell, G. S., Pharaoh, T. C., 1993. Integrated geophysical/geological modelling of the Caledonian and Precambrian basement of southern Britain. Geological Magazine 130, 593 - 604.

Busby, J. P., Smith, N.J.P. 2001. The nature of the Variscan basement in southeast England : evidence from integrated potential field modelling. Geological Magazine 138, $669-685$.

Busby, J. P., Walker, A. S. D., Rollin, K.E., 2006. Regional Geophysics of South-east England. Version 1.0 on CD-Rom. British Geological Survey, Keyworth, Nottingham, United Kingdom.

Chadwick, R. A., 1985. 14. Cretaceous sedimentation and subsidence (Cenomanian to Maastrichtian). In: Whittaker, A. (Ed.), Atlas of Onshore Sedimentary Basins in England and Wales: Post-Carboniferous Tectonics and Stratigraphy.. Blackie, Glasgow and London, 59 - 60.

Chadwick, R. A., Evans, D. J., 2005. A seismic atlas of southern Britain - images of subsurface structure. Occasional Publication No. 7. British Geological Survey, Keyworth, Nottingham, United Kingdom.

Ernst, G., Wood, C. J., Rehfeld, U., 1998. C 2.10. Cenomanian - Turonian of Soehlde. In: Mutterlose, J., Bornemann, A., Rauer, S. Spaeth, C., Wood, C. J. (Eds.), Key localities of the Northwest European Cretaceous. Bochumer Geologische und Geotechnische Arbeiten 48, 102 - 120.

Gale, A. S., 1995. Cyclostratigraphy and correlation of the Cenomanian Stage in Western Europe. In: House, M. R., Gale, A. S. (Eds.), Orbital Forcing Timescales and Cyclostratigraphy. Special Publication of the Geological Society, London 85, 177 197.

Gale, A. S., 1996. Turonian correlation and sequence stratigraphy of the Chalk in southern England. In: Hesselbo, S. P., Parkinson, D. N. (Eds.), Sequence Stratigraphy in British Geology. Special Publication of the Geological Society, London 103. 177195. 
Gallois, R. W., 1994. Geology of the country around King’s Lynn and The Wash. Memoir of the British Geological Survey, Sheet 145 and part of 129 (England \& Wales).

Gray, D. A., 1958. Electrical resistivity marker bands in the Lower and Middle Chalk of the London Basin. Bulletin of the Geological Survey of Great Britain 15, 85 - 95.

Gray, D. A., 1965. The stratigraphical significance of electrical resistivity marker bands in the Cretaceous strata of the Leatherhead (Fetcham Mill) Borehole, Surrey. Bulletin of the Geological Survey of Great Britain, 23, 65 - 115.

Hopson, P. M., Aldiss, D. T., Smith, A. 1996. Geology of the country around Hitchin. Memoir of the British Geological Survey, Sheet 221 (England \& Wales).

Jarvis, I., Woodroof, P. B., 1984. Stratigraphy of the Cenomanian and basal Turonian (Upper Cretaceous) between Branscombe and Seaton, S E Devon, England.

Proceedings of the Geologists' Association 95, 193 - 215.

Jukes-Browne, A. J., Hill, W. 1903. The Cretaceous Rocks of Britain. Vol. 2 - The Lower and Middle Chalk of England. Memoir of the Geological Survey of the United Kingdom.

Kley, J., Voigt, T. 2008. Late Cretaceous intraplate thrusting in central Europe: Effect of Africa-Iberia-Europe convergence, not Alpine collision. Geology 36, 839 - 842.

Lake, R. D., Wilson, D. 1990. Geology of the country around Great Dunmow. Memoir of the British Geological Survey, Sheet 222 (England and Wales).

Lee, M. K., Pharaoh, T. C., Soper, N. J. 1990. Structural trends in central Britain from images of gravity and aeromagnetic fields. Journal of the Geological Society of London 147, 241 - 258.

Lee, M. K., Pharaoh, T. C., Green, C. A., 1991. Structural trends in the concealed basement of eastern England from images of regional potential field data. Annales de la Société Géologique de Belgique 114, 45 - 62.

Lee, M. K., Pharaoh, T. C, Williamson, J. P., Green, C. A., De Vos, W., 1993. Evidence on the deep structure of the Anglo-Brabant Massif from gravity and magnetic data. Geological Magazine 130, 575 - 582.

Moorlock, B. S. P., Booth, S. J., Hamblin, R. J. O., Pawley, S. J., Smith, N. J. P., Woods, M. A., 2008. Geology of the Wells-next-the-Sea district - a brief explanation of the geological map. Sheet Explanation of the British Geological Survey. 1:50 000 Sheet 130 Wells-next-the-Sea (England and Wales).

Mortimore, R. N., 1983. The stratigraphy and sedimentation of the Turonian Campanian in the Southern Province of England. Zitteliana 10, 27 - 41. 
Mortimore, R. N., 1986. Stratigraphy of the Upper Cretaceous White Chalk of Sussex. Proceedings of the Geologists' Association, 97, 97 - 139.

Mortimore, R. N., Pomerol, B., 1987. Correlation of the Upper Cretaceous White Chalk (Turonian to Campanian) in the Anglo-Paris Basin. Proceedings of the Geologists' Association 98, 97 - 143.

Mortimore, R. N., Pomerol, B., 1997. Upper Cretaceous tectonic phases and end Cretaceous inversion in the Chalk of the Anglo-Paris Basin. Proceedings of the Geologists' Association 108, 231 - 255.

Mortimore, R. N., Wood, C. J., Pomerol, B., Ernst, G., 1998. Dating the phases of the Subhercynian tectonic epoch: Late Cretaceous tectonics and eustatics in the Cretaceous basins of northern Germany compared with the Anglo-Paris Basin. Zentralblatt für Geologie und Paläontologie 1, 1996, 1349 - 1401.

Mortimore, R. N., Wood, C. J., 1986. The distribution of flint in the English Chalk, with particular reference to the 'Brandon Flint Series' and the high Turonian flint maximum. In: Sieveking, G. de C., Hart, M. B. (Eds.), The scientific study of flint and chert. Cambridge University Press, Cambridge, 7 - 20.

Mortimore, R. N, Wood, C. J., Gallois, R. W., 2001. British Upper Cretaceous Stratigraphy, Geological Conservation Review Series 23. Joint Nature Conservation Committee, Peterborough.

Murray, K. H., 1986. Correlation of electrical resistivity marker bands in the Cenomanian and Turonian Chalk from the London Basin to east Yorkshire. Report of the British Geological Survey 17, No. 8.

Mutterlose, J., Bornemann, A., Herrle, J. O., 2005. Mesozoic calcareous nannofossils - state of the art. Paläontologische Zeitschrift 79, 113 - 133.

Peake, N. B., Hancock, J. M., 1970. The Upper Cretaceous of Norfolk [reprinted with corrigenda and addenda]. In: Larwood, G. P., Funnell, B. M. (Eds.), The Geology of Norfolk. Soman-Wherry Press Ltd, Norwich, 293 - 339J.

Peake, N. B., Hancock, J. M., 2000a. The Chalk of Norfolk I 1961 - 2000. Geological Society of Norfolk Jubilee Volume, 22 - 26.

Peake, N. B., Hancock, J. M., 2000b. The Chalk of Norfolk II 1961 - 2000.

Geological Society of Norfolk Jubilee Volume, 27 - 32.

Pearce, M. A, Jarvis, I., Swan, A. R. H., Murphy, A. M., Tocher, B. A., Edmunds, W. M. 2003. Integrating palynological and geochemical data in a new approach to palaeoecological studies: Upper Cretaceous of the Banterwick Barn Chalk borehole, Berkshire, UK. Marine Micropalaeontology 47, 271 - 306.

Pharaoh, T. C., Vincent, C. J., Bentham, M. S., Hulbert, A. G., Waters, C. N., Smith, N. J. P., 2011. Structure and evolution of the East Midlands region of the Pennine Basin. Subsurface Memoir of the British Geological Survey. 
Rawson, P. F., Allen, P., Gale, A. S. 2001. The Chalk Group - a revised lithostratigraphy. Geoscientist 11, 21.

Robinson, N. D., 1986. Lithostratigraphy of the Chalk Group of the North Downs, southeast England. Proceedings of the Geologists' Association 97, 141 - 170.

Schulz, K. G, Zondervan, I., Gerringa, L. J. A., Timmermans, K. R., Veldhuis, M. J. W., Riebesell, U. 2004. Effect of trace metal availability on coccolithophorid calcification. Nature 430, $673-676$.

Shephard-Thorn, E. R., Moorlock, B. S. P., Cox, B. M., Allsop, J. M., Wood, C. J., 1994. Geology of the country around Leighton Buzzard. Memoir of the British Geological Survey, Sheet 220 (England \& Wales).

Smith, N. J. P. (compiler), 1985. Map 1. Pre-Permian geology of the United Kingdom (South), 1:1 000 000. Ordnance Survey for the British Geological Survey, Southampton.

Smith, N. J. P., Kirby, G. A., Pharaoh, T. C., 2005. Structure and evolution of the south-west Pennine Basin and adjacent area. Subsurface Memoir of the British Geological Survey.

Ward, W. H., Burland, J. B., Gallois, R. W., 1968. Geotechnical assessment of a site at Mundford, Norfolk, for a large Proton Accelerator. Géotechnique 18, 399 - 431.

Whitham, F., 1991. The stratigraphy of the Upper Cretaceous Ferriby, Welton and Burnham formations north of the Humber, north-east England. Proceedings of the Yorkshire Geological Society 48, 227 - 255.

Whitham, F., 1993. The stratigraphy of the Upper Cretaceous Flamborough Chalk Formation north of the Humber, north-east England. Proceedings of the Yorkshire Geological Society 49, 235 - 258.

Wood, C. J., 1986. Appendix. 14 - 18 in Murray, K. H. Correlation of electrical resistivity marker bands in the Cenomanian and Turonian Chalk from the London Basin to east Yorkshire. Report of the British Geological Survey 17, No. 8.

Wood, C. J., Bristow, C. R., 1990. Chapter 3. Upper Cretaceous: Chalk. 16 - 29 in Bristow, C. R. Geology of the country around Bury St Edmunds. Memoir of the British Geological Survey, Sheet 189 (England \& Wales).

Wood C. J., Smith, E. G., 1978. Lithostratigraphical classification of the Chalk in North Yorkshire, Humberside and Lincolnshire. Proceedings of the Yorkshire Geological Society 42, $263-287$.

Woods, M. A., Aldiss, D. T., 2004. The stratigraphy of the Chalk Group of the Berkshire Downs. Proceedings of the Geologists’ Association 115, 249 - 265. 
Woods, M. A., 2006. UK Chalk Group stratigraphy (Cenomanian - Santonian) determined from borehole geophysical logs. Quarterly Journal of Engineering Geology and Hydrogeology 39, 83 - 96.

\section{FIGURE CAPTIONS}

Figure 1. Key boreholes and localities for the Chalk of East Anglia and southern England. Map excludes Superficial Deposits (Pleistocene and Holocene) which extensively cover the region north of London.

Figure 2. Stratigraphy and key marker-beds in the Chalk of East Anglia and the Wiltshire - Berkshire and Chilterns areas. Marker-bed correlations based on Mortimore and Wood (1986) and Mortimore et al. (2001). Not to scale. CEN. = Cenomanian; L. Chalk = Lower Chalk

Figure 3. Correlation of marker beds in borehole geophysical logs of the Thetford district and adjacent areas. Gamma logs labelled (g); other logs are single point or continuous resistivity. Resistivity/gamma values for individual logs increase from left to right. See Figure 1 for borehole locations.

Figure 4. Correlation and stratigraphical interpretation of borehole geophysical logs in the Chalk Group between Wiltshire and Suffolk. Gamma logs labelled (g); other logs are single point or continuous resistivity. Resistivity/gamma values for individual logs increase from left to right. ' $\mathrm{C}$ ' is a group of geophysical markers referred to in the text,; they correspond in part with the 'marker marls' of Woods and Aldiss (2004) and Woods (2006), and (with the exception of the Leatherhead Borehole) with Bands G and F2 of Murray (1986). For borehole locations see Figure 1.

Figure 5. Correlation and stratigraphical interpretation of borehole geophysical logs in the Chalk Group between Cambridgeshire and north Norfolk. Gamma logs labelled (g); other logs are single point or continuous resistivity. Resistivity/gamma values for individual logs increase from left to right. For borehole locations see Figure 1. Interpretation of the Alpheton Borehole based in part on Pattison et al. (1993, fig. 13).

Figure 6. Borehole scan imagery of disrupted flints (DF) and marl sheared along inclined fracture surface in the Brandon Satellite Borehole. Continuity of adjacent flints (F) and marls (M) suggests that the disrupted flints are synsedimentary effects, all developed in the equivalent of the New Pit Chalk Formation. Borehole depths in metres are shown on the scan images.

Figure 7. Residual Bouguer gravity anomaly map of East Anglia and southern England showing key boreholes and locations referred to in this study, and lines of correlation shown on Figures 3, 4 and 5. Red denotes positive anomalies and blue negative anomalies. Gravity anomalies ('A1 to 'A4') and gravity lineaments ('L1' and 'L2') are referred to in the text. Triangle ornament denotes hanging wall of Glinton Thrust. Inset cross section shows stratigraphical context of the Glinton Thrust at the end Early Cretaceous. See Figure 1 for key to boreholes and localities. 
Figure 8. Combined reduced-to-pole magnetic anomaly (colour), and residual Bouguer gravity anomaly (relief) map of East Anglia and southern England showing key boreholes, locations and structural features referred to in this study, and lines of correlation shown on Figures 3, 4 and 5. Positive magnetic anomalies are shown in red and negative anomalies in blue. 'L1' denotes the lineation of the major gravity anomaly formed by the Glinton Thrust in the subcrop. See Figure 1 for key to boreholes and localities.

Figure 9. Synthetic lithological and resistivity logs of the Square Plantation Borehole, and their correlation with resistivity logs for the East Harling and Stowlangtoft boreholes. Synthetic log created from borehole video log. Small depth mismatch between graphic borehole log and geophysical log caused by difficulty of interpreting precise depths from video log. Resistivity values for individual logs increase from left to right. 


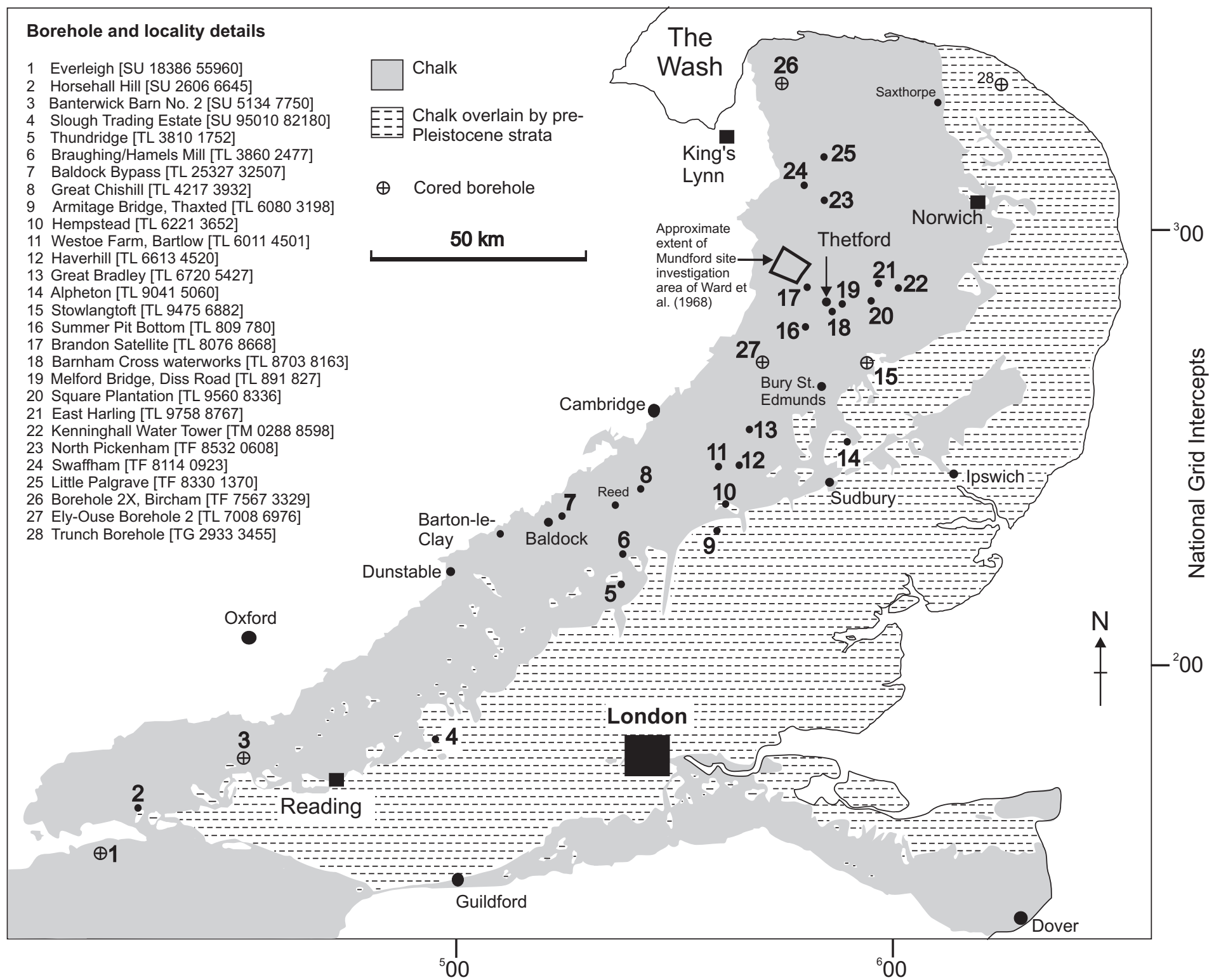




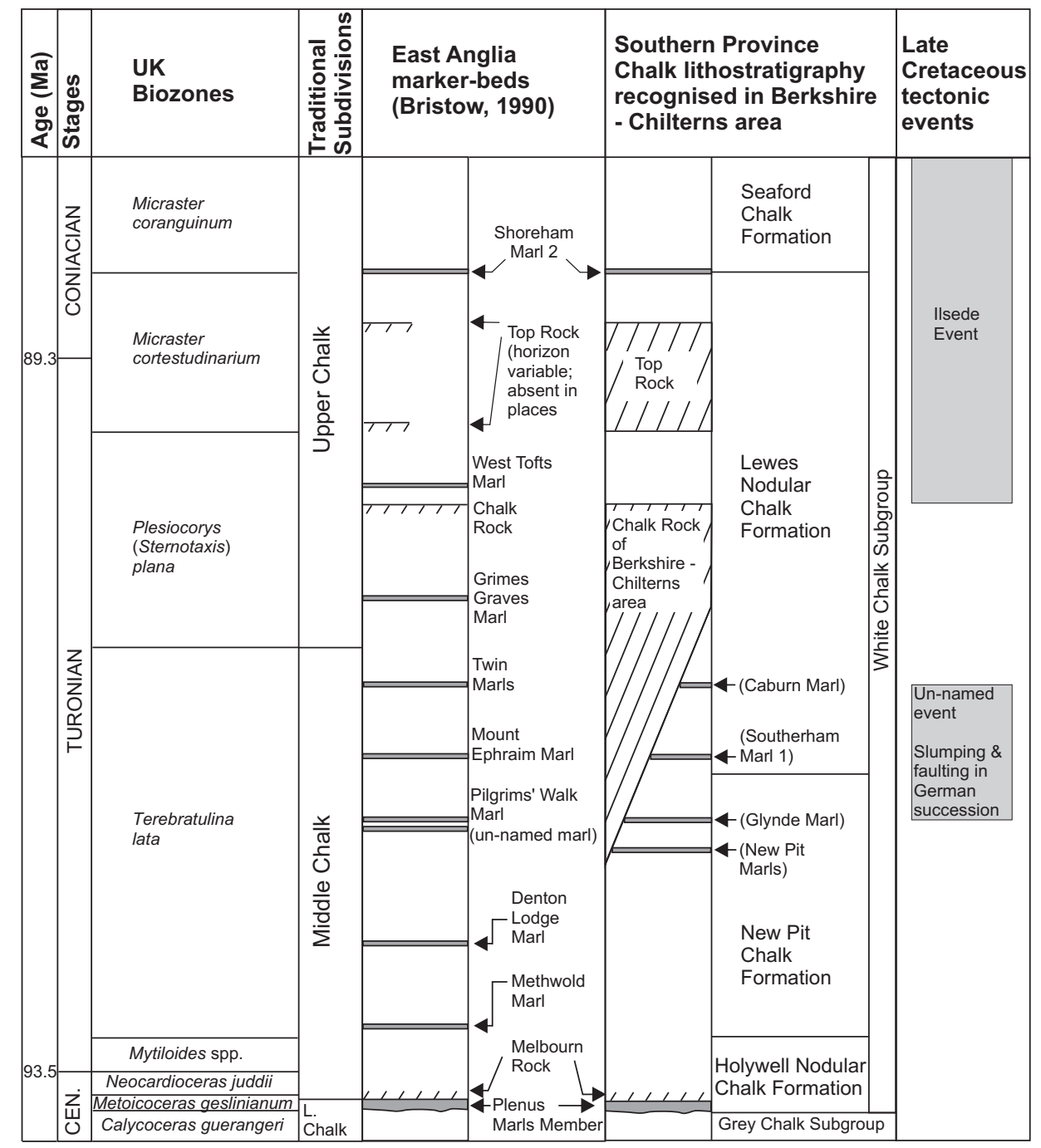

$7 /{ }^{\text {Strongly }} \begin{aligned} & \text { cemented } \\ & \text { chalk }\end{aligned}$ 


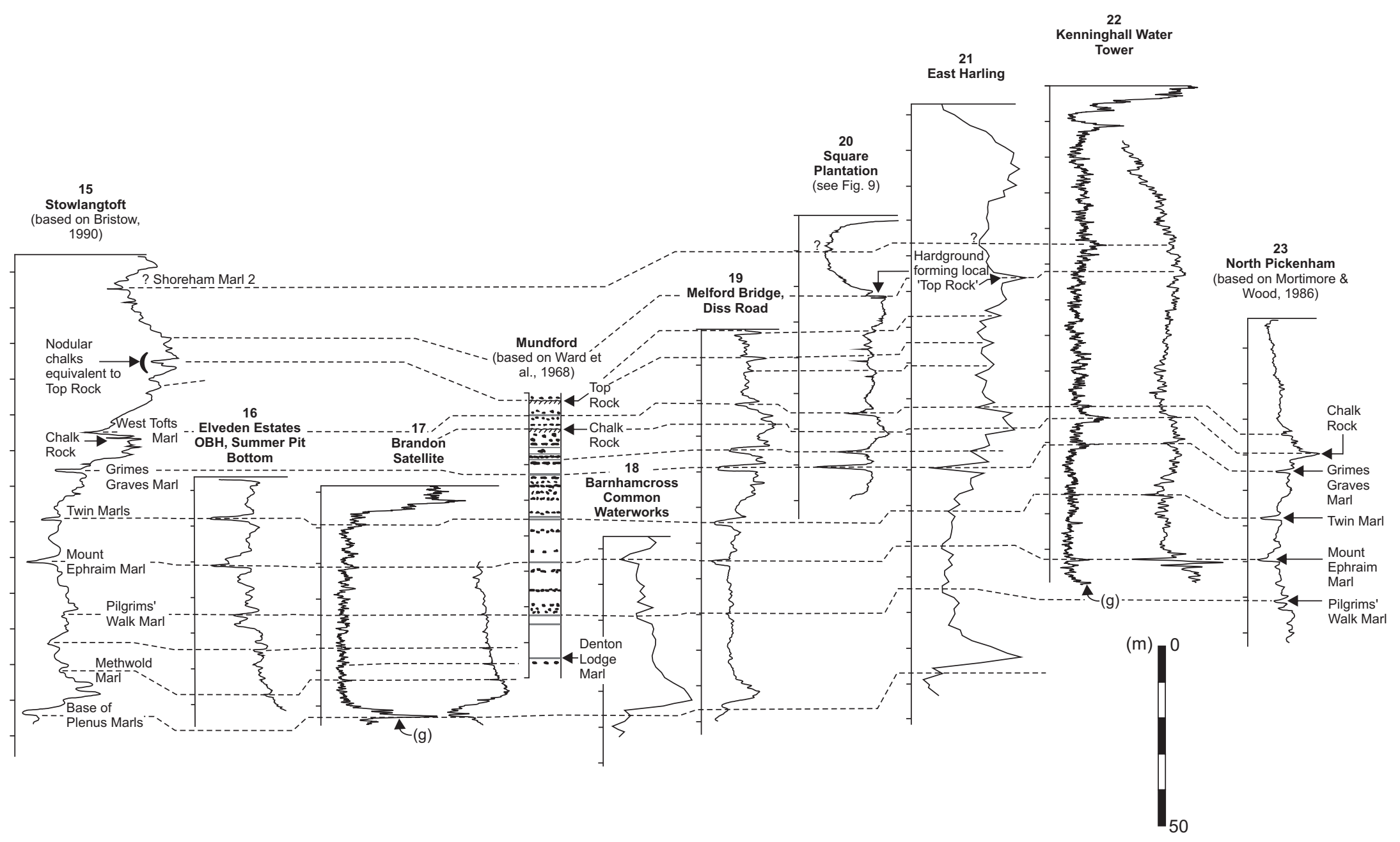




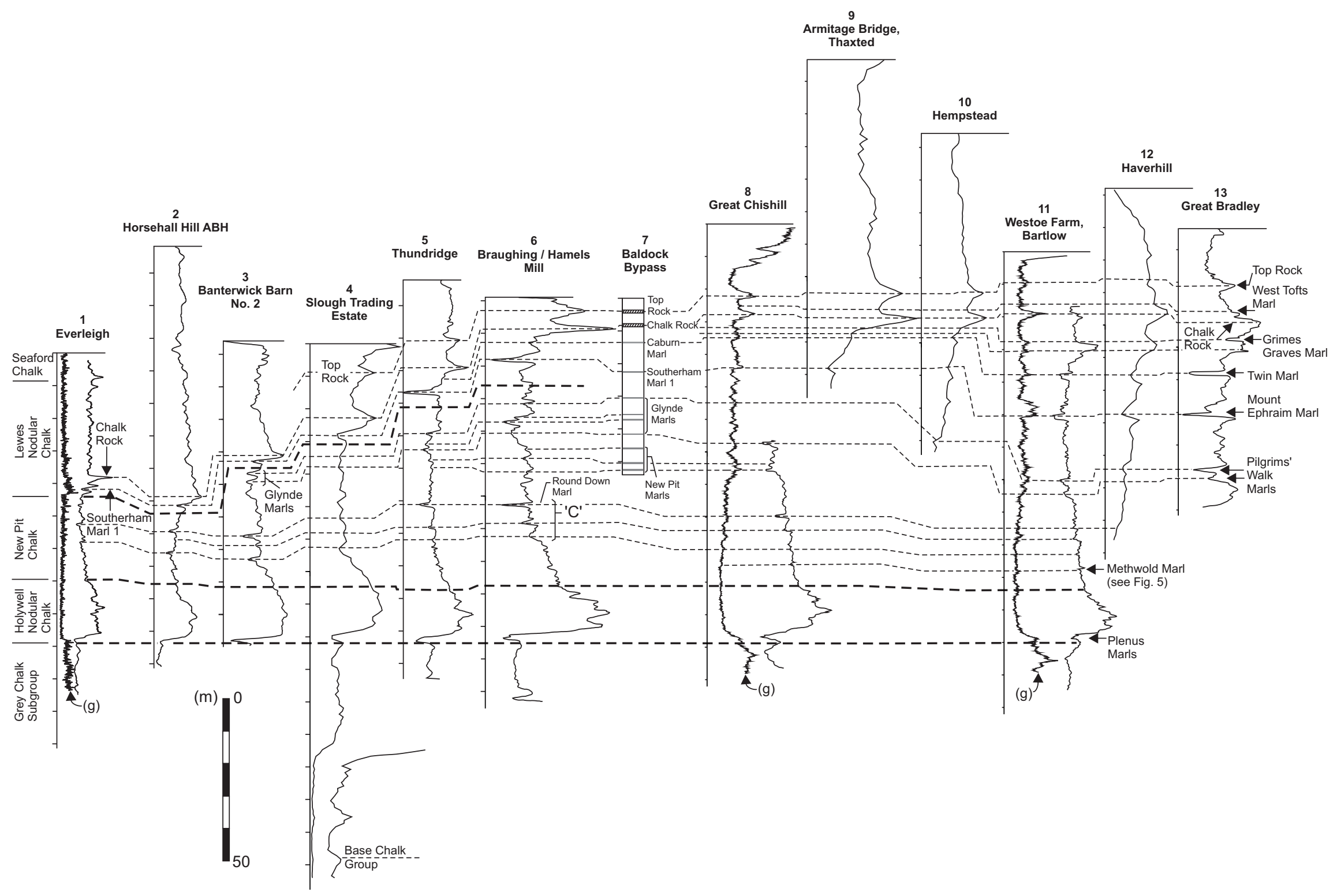




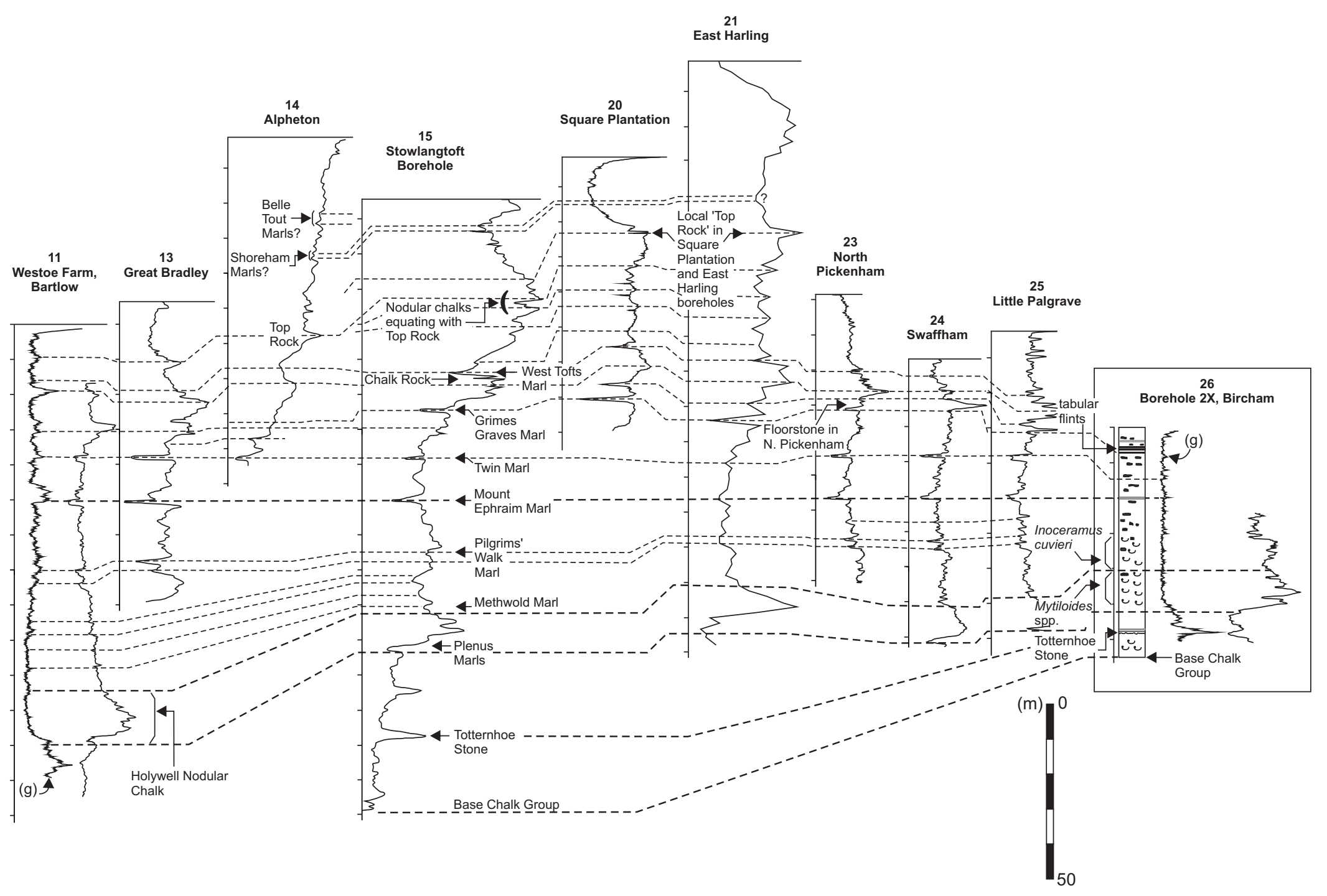




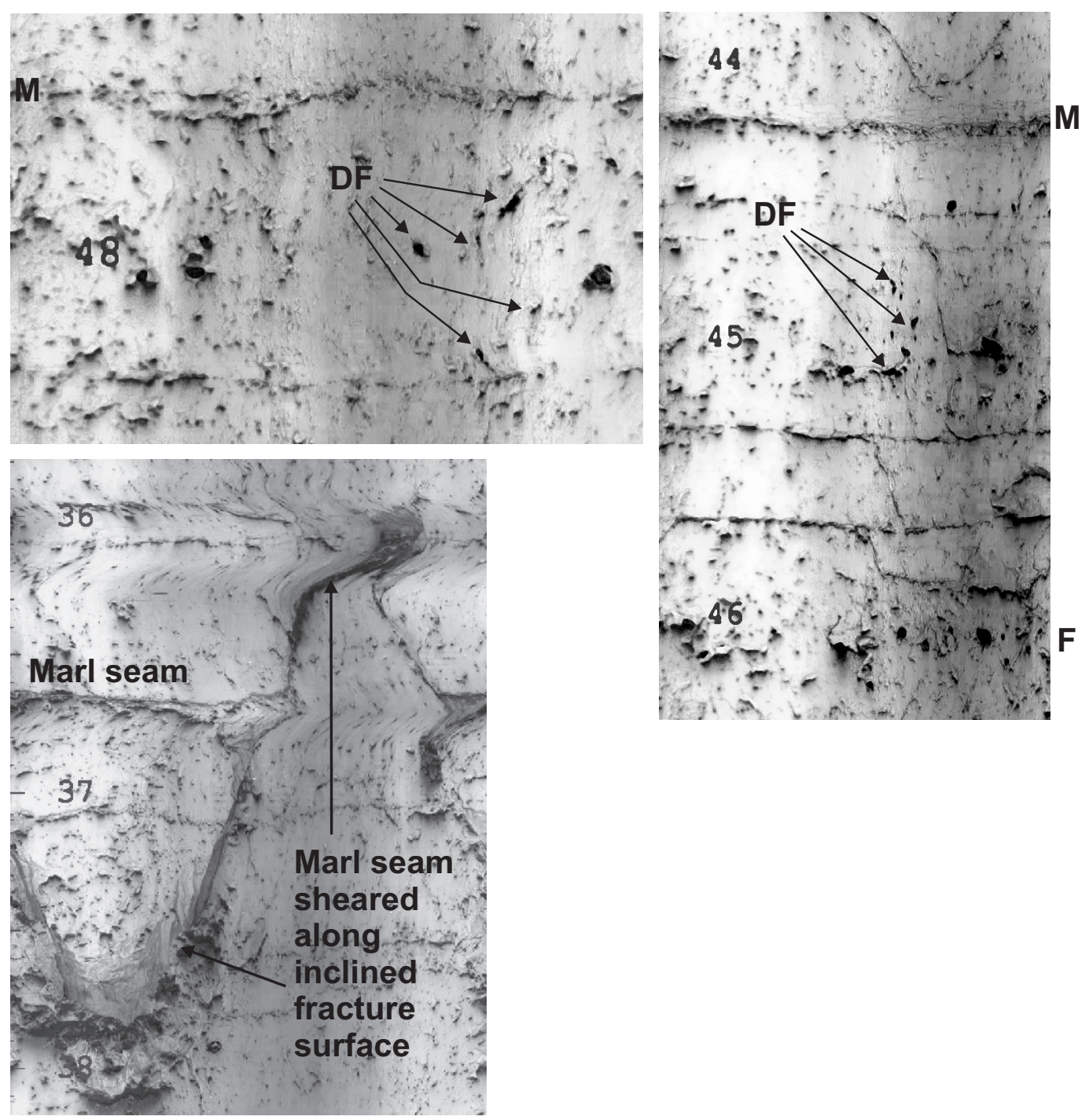




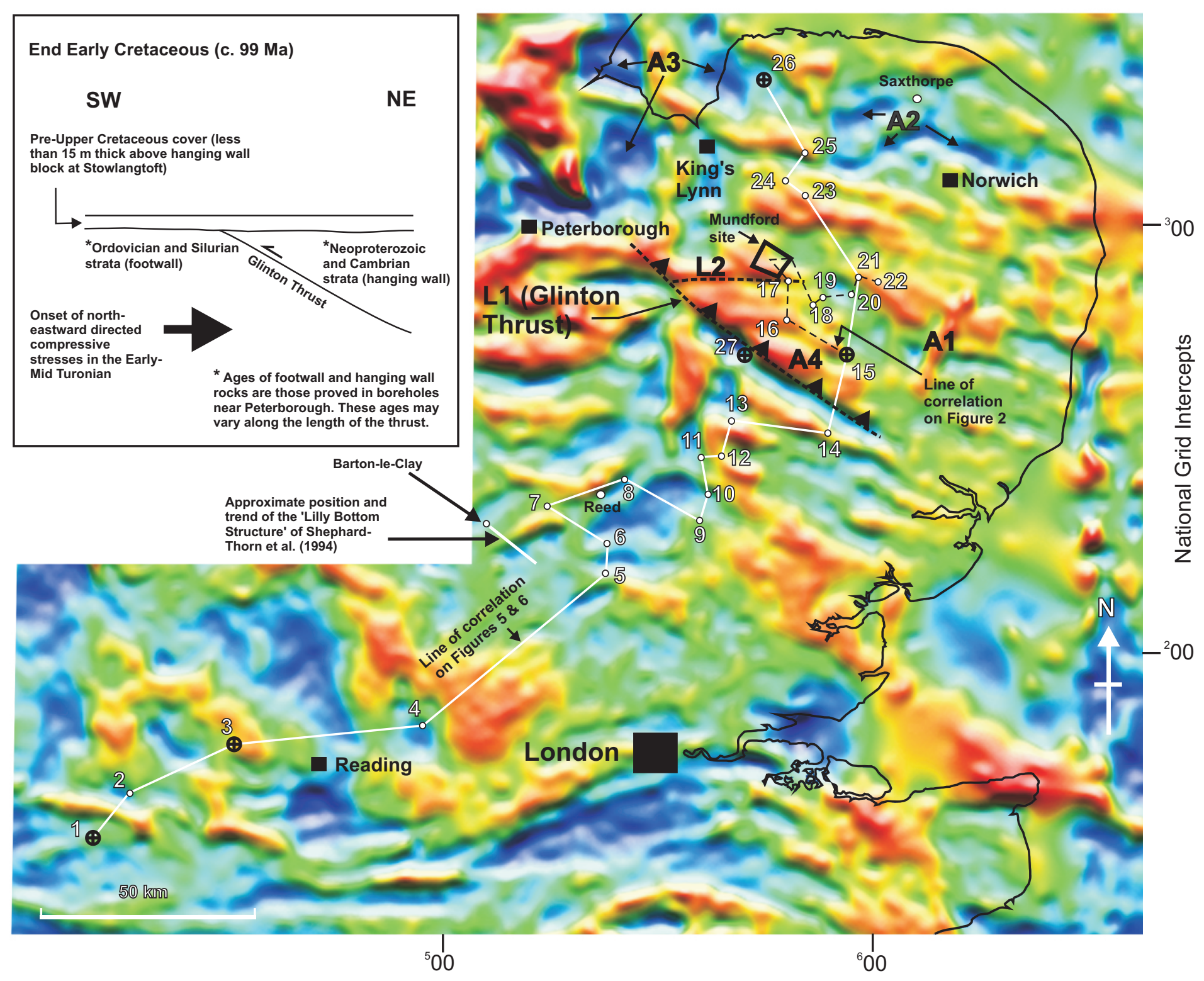




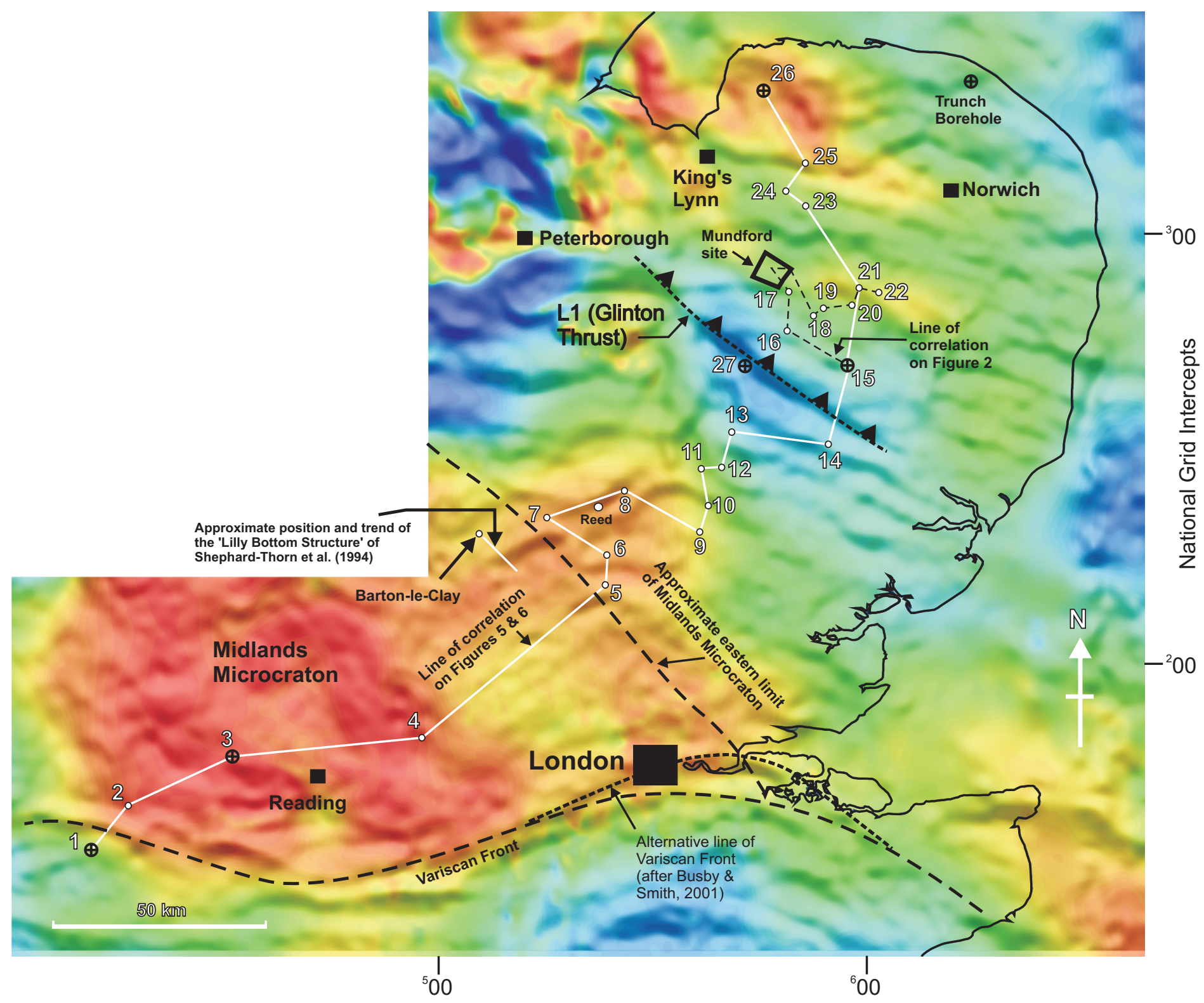




\section{Square Plantation}

(lithological log)

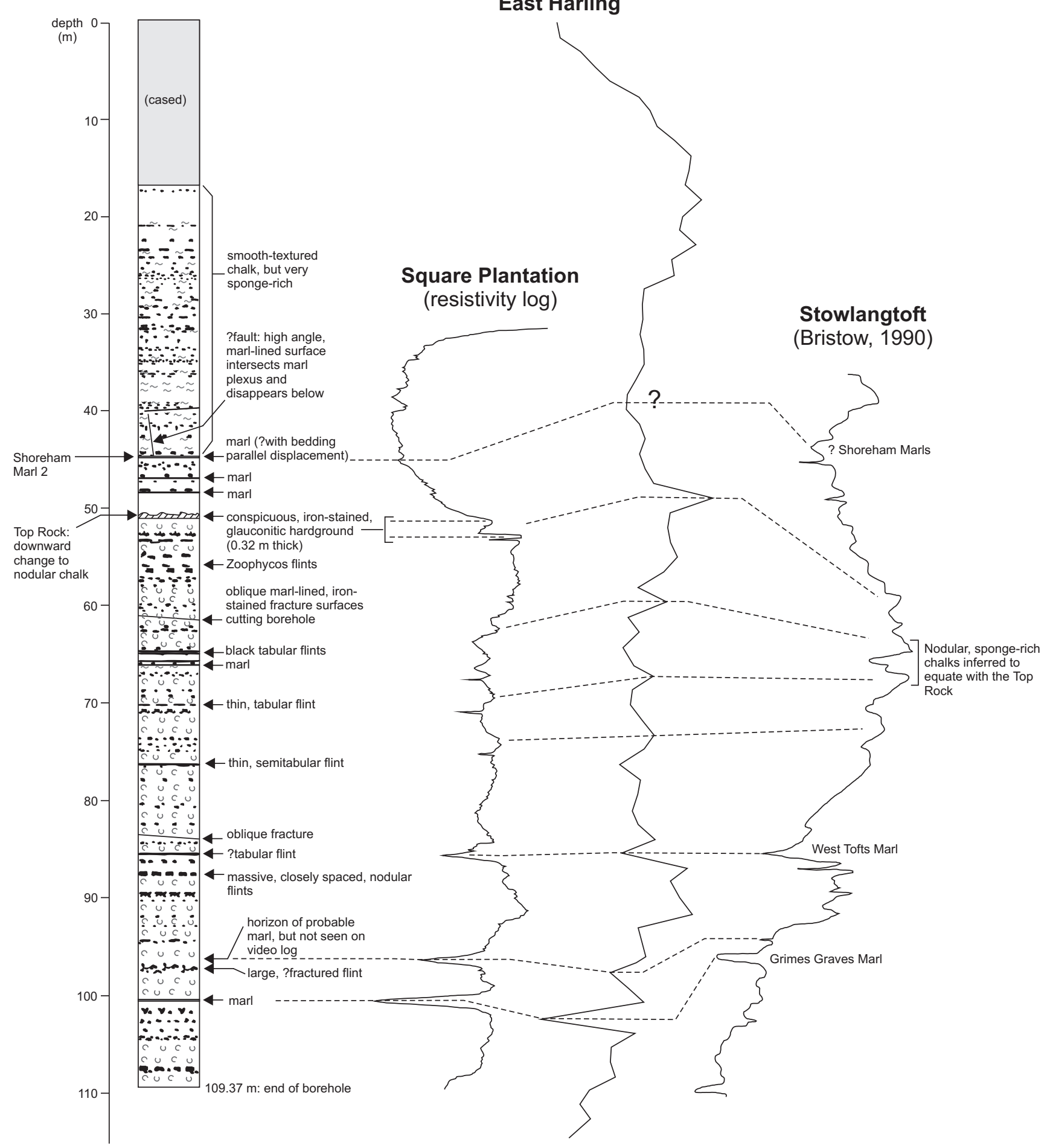

